\title{
Preliminary Results in the Study of Two Local Almond Populations from Dobrogea Region
}

\author{
Lucian CIOAC $\breve{A}^{*}$, Florin STĂNICĂ \\ University of Agronomic Sciences and Veterinary Medicine of Bucharest, Faculty of Horticulture \\ *corresponding author: cioaca_lucian@yahoo.com
}

BulletinUASVM Horticulture 77(1) / 2020

Print ISSN 1843-5254, Electronic ISSN 1843-5394

DOI:10.15835/buasvmcn-hort: 2019.0048

\begin{abstract}
The almond (Prunus dulcis L.) is a very popular nut, being one of the most complex fruits for the benefit of the human health. Nowadays in Romania, this crop started to decrease as covered land and production. At the global level the cultivated surfaces and the production is on raise. The aim of our study was to select better almond genotypes suitable for breeding. The study's goal was to monitor two spontaneous populations of almond hybrids naturally formed in two distinct localities from the Dobrogea region, namely Greci, from Tulcea county and Crucea, from Constanta county. Naturally formed almond hybrids were studied and observations have been performed for the phenophases in the years 2018 and 2019, also observing the presence of different pathogenic diseases on the phyllosphere of the plants. There were also accomplished morphological measurements for the hybrids of high interest according to the purpose of the present research work.
\end{abstract}

Keywords: breeding, Prunus dulcis, spontaneous hybrids

\section{Introduction}

The almond is native to Southeast Asia, historically known region as the "the horn of abundance", located on the territories of Palestine, Syria, Lebanon, Iran, Iraq and eastern Turkey (Albala 2009).

It is a species adapted to a harsh climate, with the capacity to develop a deep and extended root system in the centrifugal way, these characteristics allowing the almond to explore a wide range of ecological niches, being adapted to conditions with mild and dry winters, warm summers, typical to the Mediterranean climate (Cociu, 2011).

The almond is among the fruit trees from the temperate zone that blooms first, has impressively beautiful large flowers, making almond a symbol of hope (Socias et al., 2017).
Recently, the global demand has steadily increased over the last decades, favoring new plantations and increasing production. The demand was favored through ongoing studies that demonstrate the health benefits of regular almond consumption (Hoy 2004).

In Romania, at SCDP Oradea, SCDP Constanţa and ICDP Mărăcineni there were few breeding programs to improve the almond varieties after 1990. The orchards established before 1990 are no longer productive and for various reasons, the almond crop presents less interest for today's farmers, resulting in surfaces occupied by this culture to decrease more and more.

The statistics made public by FAO (Fig. 1), for the period 1997-2017, shows a raise in the area cultivated with almonds worldwide also in 


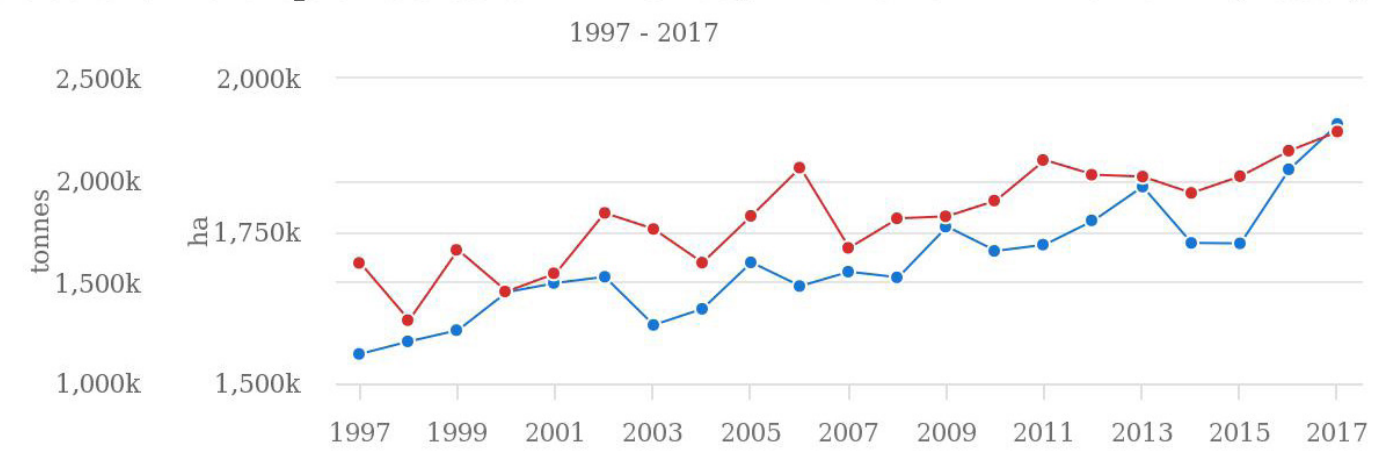

Figure 1. Worldwide areas occupied by the almond crop and the global production for the period $1997-2017$

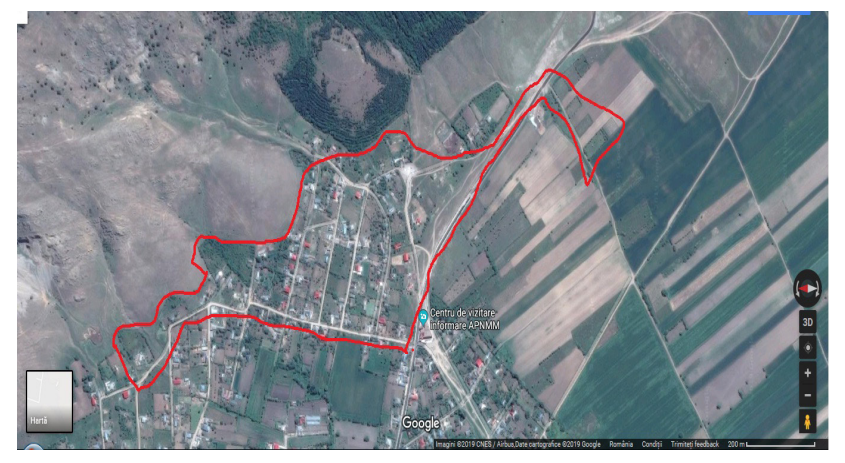

Figure 2. First area taken into study, Greci, TL (maps.google.com)

the global almond production. The production between 1997 and 2017, by continents, shows that North America is the main worldwide almond producer, followed by Asia and Europe.

Currently, in Romania, the total area covered by fruit crops is 137263 ha, which represents about $1.7 \%$ of the arable land of the country, being concentrated in several counties (insse.ro, 2018).

The structure of the fruit tree plantations shows that the nut crop covers 2,231 ha, representing $1.42 \%$ of the total area cultivated with fruit trees in Romania. There are no statistics about the area occupied by the almond crops (Ghid tehnic, 2014).

In the counties taken into study, the areas occupied with orchards are 2,753 ha in Constanta, of which 25 ha with nut crops and 1,438 ha in Tulcea, of which 95 ha nut crops (Ghid tehnic, 2014).

Obtaining and introducing in production new varieties can significantly contribute to the revitalization of the almond culture in Romania.

The aim of our study was to select better almond genotypes suitable for breeding. To achieve

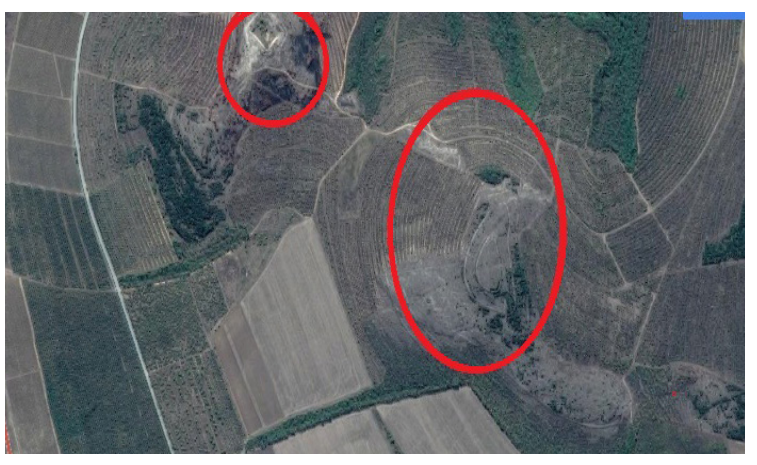

Figure 3. Second area taken into study, Crucea, CT (maps.google.com)

the goal, there were two spontaneous populations of almond hybrids naturally formed in this two distinct localities from Dobrogea, namely Greci, from Tulcea county and Crucea, from Constanta county.

\section{Materials and methods}

For breeding almond varieties, late flowering and the genetic resistance to pathogenic diseases are characteristics of high interest in our country. Thus, we studied only the natural formed hybrids that produce flowers.

The first area taken into study (Fig. 2) is on the administrative territory of Greci commune, Tulcea county. Here there were studied 163 almond hybrids, descendants of unknown genitors, most likely natural formed hybrids in their turn.

The second area taken into study (Fig. 3) is on the administrative territory of Crucea commune, Constanta county, near the Crucea fruit farm. At the Crucea fruit farm are 55 ha of almonds cultivated in ecological system, from which resulted 140 almond hybrids that we studied. The following varieties of almond are cultivated at the Crucea 


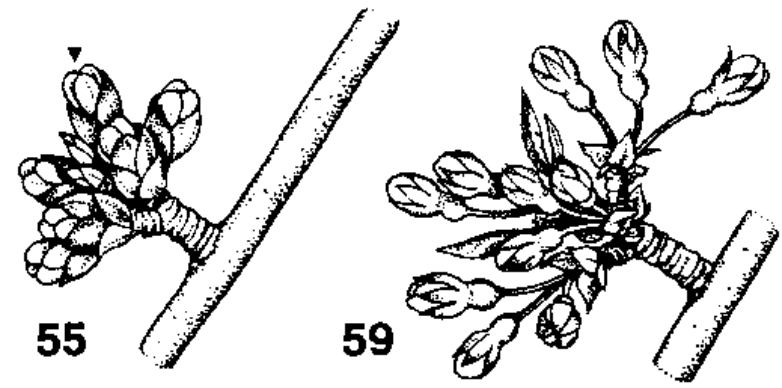

Figure 4. Growth stage 55 and 59 (Meier et al., 2001)

farm and are the possible genitors of the studied hybrids: 'Preanii', 'Teteny Boterno', 'Ai', 'Mari de stepa,' 'Nikitschi pozno', 'Nikitschi 62', 'Sudak', 'De yalta', 'Feragnes', 'Feraduel'.

The methods of study were:

Observations have been made on the phenological development stages in 2018 and 2019 vegetation years for the almonds under study, taking into consideration the BBCH scale (Meier et al., 2001), for the stone fruit trees and followed the Principal growth stage 5: Inflorescence emergence and Principal growth stage 6: Flowering.

The keys for identifying each stage, for the growth stage 5, are the following: 51: Inflorescence buds swelling; 53: Bud burst: scales separated, light green bud sections visible; 54: Inflorescence enclosed by light green scales; 55: Single flower buds visible borne on short stalks, green scales slightly open (Fig. 4); 56: Flower pedicel elongating; sepals closed; single flowers separating; 57 Sepals open: petal tips visible; single flowers with white or pink petals still closed; 59: Most flowers with petals forming a hollow ball (Fig. 4). For identifying the growth stage 6, the keys are: 60 : First flowers open; 61: Beginning of flowering: about $10 \%$ of flowers open; 62 : About $20 \%$ of flowers open; 63: About 30\% of flowers open; 64: About $40 \%$ of flowers open; 65: Full flowering: at least $50 \%$ of flowers open, first petals falling; 67 : Flowers fading: majority of petals fallen; 69: End of flowering: all petals fallen. (Meyer et al., 2001)

The second method of study was observing the resistance to various pathogenic diseases. The diseases observed are the following:

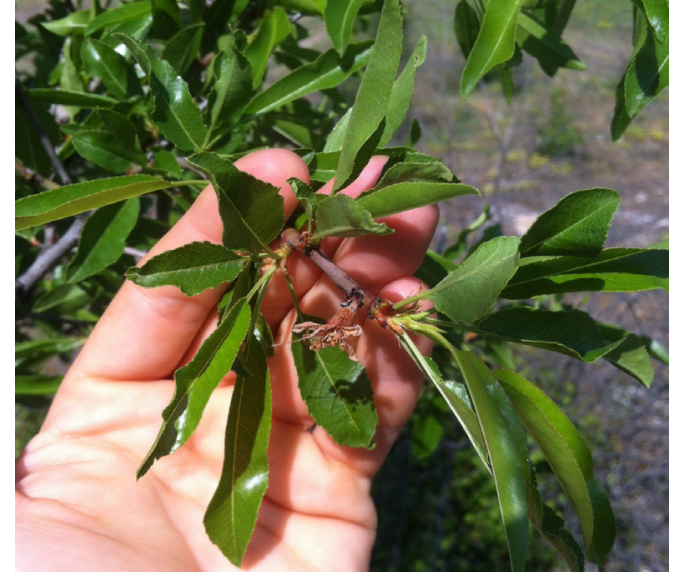

Figure 5. Monilinia laxa or brown rot

Monilinia laxa [(Aderh. \& Ruhland) Honey], popular known as brown rot (Fig. 5). The pathogen infects aerial parts of host plants with a variety of symptoms, including blighting of blossoms, cankers on woody tissues and rotting of fruits. Blossom blight is the first symptom in the spring. (Leeuwen and Kesteren, 1998)

Pseudomonas syringae (Van Hall), known as bacterial canker. On the stems and spurs, dead areas of bark develop in spring and early summer, often accompanied by gummy ooze. The emerging shoots, it is possible either to fail, either to start growing normally in spring before dying back rapidly. On the leaves appear small brown spots that will fall out later to leave holes. (Minoiu and Lefter, 1987)

Stigmina carpophila [(Lev.) MB Ellis], known also as shot hole disease (Fig. 6). On leaves, the symptoms of shot-hole disease range from small reddish or purplish, with yellow halo bordered spots, the center of which drops out as the spot ages, to larger, irregular, reddish-brown spots occurring usually along the leaf margin - where the affected area also drops out. On twigs, the symptoms are small black spots, which later enlarge and become sunken (Woodward, 1999).

Taphrina deformans [(Berk.) Tul.], known as leaf curl, it produces a red colouration, and tissue distortion in infected regions (Syrop, 1975).

Polystigma fulvum (Pers. Ex DC.) or red leaf blotch (Fig. 7), presents the following symptoms: pale green spots appear on both sides of the leaves, turning yellowish-orange. The spots are growing, ending up covering most of the leaf surface in the late summer. In advanced stages of the disease, 


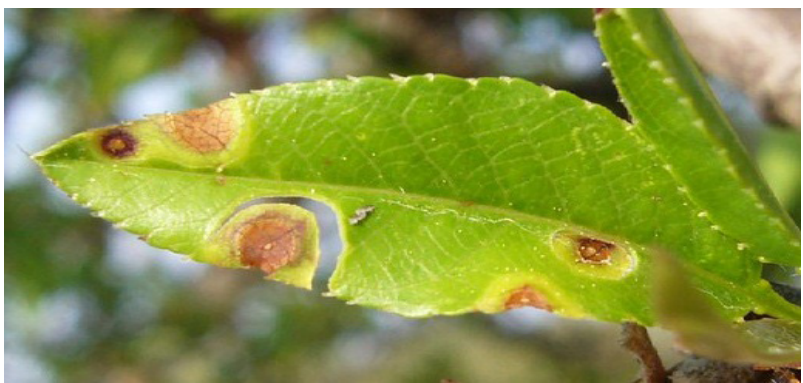

Figure 6. Stigmina carpophila or shot hole disease

leaves curl and become necrotic. Red leaf blotch can lead to a premature defoliation. (Lopez-Lopez et al., 2016)

The presence of the diseases on the fruit trees taken into study was observed between February and September 2018.

The third method of study was realizing morphological measurements on the almond hybrids that were of high interest in accomplishing our aim. The following measurements were carried out: the tree height, trunk height, crown height, diameter at $50 \mathrm{~cm}$ above the ground level, cross sectional surface, crown diameter, crown volume, crown type, branch angles, trees tendency of basitony or acrotony, altitude and exposure.

The measurement instruments were: a $5 \mathrm{~m}$ telescopic leveling rod, a dendrometric roulette for measuring diameters, a simple roulette and the mobile phone.

The heights of the trees, the heights of the trunks and the heights of the crowns were measured with the $5 \mathrm{~m}$ telescopic leveling rod.

The diameter at $50 \mathrm{~cm}$ above the ground level was measured with the dendrometric roulette.

The diameter of the crown was determined by measuring the projection of the trees crown, measuring on two distinct directions, on the cardinal points $\mathrm{N}-\mathrm{S}$ and $\mathrm{E}-\mathrm{V}$, realizing the average of the measured values, for each almond.

The volume of the crown resulted from the multiplication of two values: the height of the crown and the diameter of the crown.

The cross sectional surface was calculated by the area of the circle formula, where

$$
\operatorname{SST}=\pi / 4^{*} d^{2} .
$$

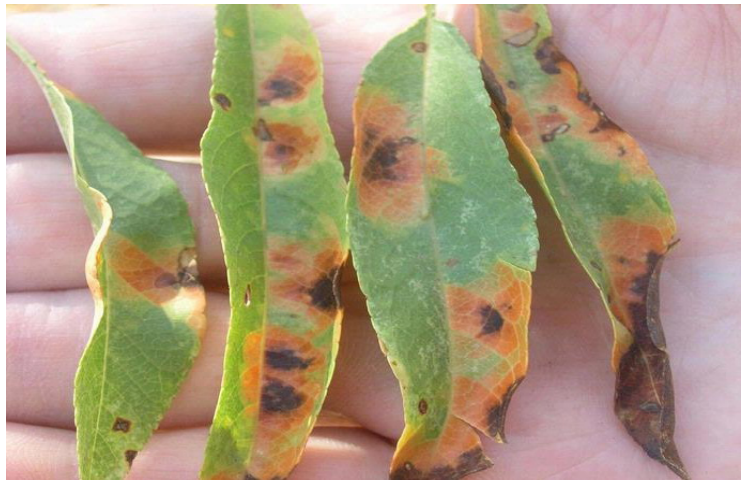

Figure 7. Polystigma fulvum or red leaf blotch

The altitude and exposure was determined through a mobile phone application, called Altimeter. The land exposure in Greci is S-W, in Crucea the land exposure is $\mathrm{E}$.

\section{Results and discussions}

In Greci have been studied 163 almonds, two of them were of high interest for our study. In 2018 the emergence of the inflorescence begun on $8^{\text {th }}$ March, flowering ending on $14^{\text {th }}$ April. In 2019 the emergence of the inflorescence begun on $24^{\text {th }}$ February, flowering ending on the $2^{\text {nd }}$ of April. In Table 1 is presented the phenology of the almonds studied in Greci.

In Greci was observed the presence of different pathogenic diseases on the filosphere of the almonds taken into study and noted, the presence of a pathogen with yes (y), its absence by no (n), plus a conclusion (Tab. 2).

From the observations performed in Greci, it resulted that hybrid no. 4, has genetic resistance to pathogenic diseases and hybrid no. 33 , is relatively sensible to them.

The morphological characters measured in Greci, are presented in Table 3.

In Crucea have been studied 140 almonds, 11 of them were of high interest for our study. In 2018 the emergence of the inflorescence begun on $27^{\text {th }}$ March, flowering ending on $20^{\text {th }}$ April. In 2019 the emergence of the inflorescence begun on $23^{\text {th }}$ February, flowering ending on the $10^{\text {th }}$ of April. In Table 4 is presented the phenology of the almonds studied in Crucea.

In Crucea, we observed the presence of pathogenic diseases on the almonds taken into study. The presence of a pathogen was noted by yes (y), the absence by no (n) (Tab. 5). 
Table 1. Phenological development stages for the almonds taken into study in Greci

\begin{tabular}{|c|c|c|c|c|}
\hline $\begin{array}{c}\text { Phenological stage / } \\
\text { Hybrid }\end{array}$ & $\mathrm{H} 4$ & $\mathrm{H} 4$ & H33 & H33 \\
\hline & 2018 & 2019 & 2018 & 2019 \\
\hline 53 & 08-Mar & $24-\mathrm{Feb}$ & & \\
\hline 54 & & 02-Mar & & 24-Feb \\
\hline 55 & 15-Mar & 09-Mar & 08-Mar & 02-Mar \\
\hline 56 & & & & 09-Mar \\
\hline 57 & & 16-Mar & 15-Mar & \\
\hline 59 & & 20-Mar & & 16-Mar \\
\hline 60 & & & & \\
\hline 61 & & & 31-Mar & 20-Mar \\
\hline 63 & 31-Mar & & & \\
\hline 64 & & 27-Mar & & \\
\hline 65 & 07-Apr & & 07-Apr & \\
\hline 67 & & & & 27-Mar \\
\hline 69 & 14-Apr & 02-Apr & 14-Apr & 02-Apr \\
\hline
\end{tabular}

Table 2. The presence of different pathogenic diseases on the almonds from Greci

\begin{tabular}{ccccccc}
\hline No & Monilinia & Pseudomonas & Stigmina & Taphrina & Polystigma & Conclusion \\
\hline $\mathbf{4}$ & $\mathrm{y}$ & $\mathrm{n}$ & $\mathrm{n}$ & $\mathrm{y}$ & $\mathrm{n}$ & Resistant \\
\hline $\mathbf{3 3}$ & $\mathrm{y}$ & $\mathrm{y}$ & $\mathrm{n}$ & $\mathrm{y}$ & $\mathrm{y}$ & Relatively sensible \\
\hline
\end{tabular}

Table 3. The morphological data of the almond hybrids measured in Greci

\begin{tabular}{cccc}
\hline Column1 & H4 & H33 & Average \\
\hline Tree h & 2.15 & 3.22 & 2.685 \\
\hline Trunk h & 0.83 & 0.85 & 0.84 \\
\hline Crown h & 1.32 & 2.37 & 1.845 \\
\hline d 50 cm a.g. & 0.02 & 0.05 & 0.035 \\
\hline CSS (m2) & 0.03 & 0.19 & 0.11 \\
\hline Crown d & 0.95 & 1.8 & 1.375 \\
\hline Crown vol. (m3) & 1.25 & 4.26 & \\
\hline Crown type & globe & globe & \\
\hline Ramify angle & big & big & \\
\hline B/A & acrotony & acrotony &
\end{tabular}

From the 11 hybrids under observation in Crucea, hybrid no. 129 has genetic resistance to pathogenic diseases, the others being relatively resistant, relatively sensible or sensible to pathogens.

In Crucea, the almond hybrids that were of high interest for our study, are presented in table 6.

\section{Conclusion}

In Greci, 163 almond hybrids formed naturally were studied. Two of them were of high interest in selecting possible genitors for breeding new varieties. In Crucea, were studied 140 almonds,
11 of them presented high interest in selecting possible genitors for breeding better varieties.

In both places of study, the hybrids observed presented late flowering. The almonds studied in Crucea, bloom lately than the ones from Greci and could be used as possible genitors for breeding varieties that bloom late.

Hybrid no. 4 from Greci and no. 129 from Crucea, we regard as potential resistant to the pathogenic diseases taken into consideration and could be used as possible genitors for breeding varieties that are genetically resistant to the diseases investigated. 
Table 4. Phenological development stages for the almonds taken into study in Crucea

\begin{tabular}{|c|c|c|c|c|c|c|c|c|c|c|c|c|c|c|}
\hline Year & $\begin{array}{c}\text { Hybrid / } \\
\text { BBCH }\end{array}$ & 53 & 54 & 55 & 56 & 57 & 59 & 60 & 61 & 62 & 64 & 65 & 67 & 69 \\
\hline 2018 & 3 & & 27.III & & 03.IV & & & & & & & 13.IV & & 20.IV \\
\hline 2019 & 3 & 23.II & 01.III & 08.III & 13.III & 22.III & 30.III & & & & 05.IV & & & 10.IV \\
\hline 2018 & 8 & 27.III & & & & & 03.IV & & & & & 13.IV & & 20.IV \\
\hline 2019 & 8 & 23.II & & 01.III & 08.III & 13.III & 22.III & & 30.III & & & 05.IV & & 10.IV \\
\hline 2018 & 18 & & 27.III & & 03.IV & & & & & & & 13.IV & & 20.IV \\
\hline 2019 & 18 & 23.II & 01.III & 08.III & 15.III & 22.III & 30.III & & & & & 05.IV & & 10.IV \\
\hline 2018 & 24 & 27.III & & & 03.IV & & & & & & & & 13.IV & 20.IV \\
\hline 2019 & 24 & 23.II & 01.III & 08.III & 15.III & 22.III & 30.III & & & & & 05.IV & & 10.IV \\
\hline 2018 & 40 & & & & 03.IV & & & & & & & 13.IV & & 20.IV \\
\hline 2019 & 40 & & & & & & & & & & & & & \\
\hline 2018 & 46 & & & & 03.IV & & & & & & & 13.IV & & 20.IV \\
\hline 2019 & 46 & 23.II & & 01.III & 08.III & 15.III & & 22.III & & 30.III & & 05.IV & & 10.IV \\
\hline 2018 & 56 & & & & 03.IV & & & & & & & 13.IV & & 20.IV \\
\hline 2019 & 56 & 23.II & 01.III & 08.III & 15.III & 22.III & 30.III & & & & 05.IV & & & 10.IV \\
\hline 2018 & 57 & & & & 03.IV & & & & & & & 13.IV & & 20.IV \\
\hline 2019 & 57 & 23.II & 01.III & 08.III & 15.III & 22.III & 30.III & & & & 05.IV & & & 10.IV \\
\hline 2018 & 66 & & & & 03.IV & & & & & & & 13.IV & & 20.IV \\
\hline 2019 & 66 & & 23.II & 01.III & 08.III & 15.III & 22.III & 30.III & & & & 05.IV & & 10.IV \\
\hline 2018 & 68 & & & & 03.IV & & & & & & & 13.IV & & 20.IV \\
\hline 2019 & 68 & & 23.II & 01.III & 08.III & 15.III & 22.III & 30.III & & & & $05 . I V$ & & 10.IV \\
\hline 2018 & 129 & & 03.IV & & & & & & & & 13.IV & & & 20.IV \\
\hline 2019 & 129 & 23.II & 01.III & 08.III & 15.III & 22.III & 30.III & & & & 05.IV & & & 10.IV \\
\hline
\end{tabular}

Table 5. The presence of different pathogenic diseases on the almonds from Crucea

\begin{tabular}{ccccccc}
\hline No & Monilinia & Pseudomonas & Stigmina & Taphrina & Polystigma & Conclusion \\
\hline $\mathbf{3}$ & $\mathrm{y}$ & $\mathrm{y}$ & $\mathrm{n}$ & $\mathrm{n}$ & $\mathrm{y}$ & Relatively Resistant \\
\hline $\mathbf{8}$ & $\mathrm{n}$ & $\mathrm{y}$ & $\mathrm{y}$ & $\mathrm{n}$ & $\mathrm{y}$ & Relatively Resistant \\
\hline $\mathbf{1 8}$ & $\mathbf{2}$ & $\mathrm{y}$ & $\mathrm{y}$ & $\mathrm{y}$ & $\mathrm{y}$ & Sensible \\
\hline $\mathbf{2 4}$ & $\mathrm{y}$ & $\mathrm{y}$ & $\mathrm{y}$ & $\mathrm{n}$ & $\mathrm{y}$ & Relatively Sensible \\
\hline $\mathbf{4 0}$ & $\mathrm{y}$ & $\mathrm{y}$ & $\mathrm{y}$ & $\mathrm{d}$ & $\mathrm{y}$ & Sensible \\
\hline $\mathbf{4 6}$ & $\mathrm{y}$ & $\mathrm{y}$ & $\mathrm{y}$ & $\mathrm{y}$ & $\mathrm{y}$ & Sensible \\
\hline $\mathbf{5 6}$ & $\mathrm{n}$ & $\mathrm{y}$ & $\mathrm{y}$ & $\mathrm{y}$ & $\mathrm{y}$ & Relatively Sensible \\
\hline $\mathbf{5 7}$ & $\mathrm{y}$ & $\mathrm{y}$ & $\mathrm{y}$ & $\mathrm{n}$ & $\mathrm{y}$ & Relatively Sensible \\
\hline $\mathbf{6 6}$ & $\mathrm{y}$ & $\mathrm{y}$ & $\mathrm{y}$ & $\mathrm{n}$ & $\mathrm{Y}$ & Relatively Sensible \\
\hline $\mathbf{6 8}$ & $\mathrm{n}$ & $\mathrm{y}$ & $\mathrm{y}$ & $\mathrm{n}$ & $\mathrm{y}$ & Relatively Resistant \\
\hline $\mathbf{1 2 9}$ & $\mathrm{n}$ & $\mathrm{n}$ & $\mathrm{y}$ & $\mathrm{n}$ & $\mathrm{y}$ & Resistant \\
\hline
\end{tabular}

Table 6. The morphological data of the almond hybrids measured in Crucea

\begin{tabular}{|c|c|c|c|c|c|c|c|c|c|c|}
\hline No & Tree h & Trunk h & Crown h & $\begin{array}{l}\text { d } 50 \mathrm{~cm} \\
\text { a. g. }\end{array}$ & $\operatorname{CSS}\left(\mathrm{m}^{2}\right)$ & Crown d & $\begin{array}{c}\text { Crown vol. } \\
\left(\mathrm{m}^{3}\right)\end{array}$ & $\begin{array}{c}\text { Crown } \\
\text { type }\end{array}$ & $\begin{array}{c}\text { Ramify } \\
\text { angle }\end{array}$ & B/A \\
\hline 3 & 3.7 & 0.65 & 3.05 & 0.17 & 0.0226 & 4.15 & 12.57 & globe & big & acrotony \\
\hline 8 & 2 & 0.1 & 2.9 & 0.04 & 0.00012 & 1.3 & 3.84 & globe & big & acrotony \\
\hline 18 & 1.32 & 0.2 & 1.12 & 0.02 & 0.00003 & 0.8 & 0.56 & globe & big & acrotony \\
\hline 24 & 1.9 & 0.25 & 1.65 & 0.05 & 0.00019 & 1.3 & 2.18 & globe & big & acrotony \\
\hline 40 & 2.75 & 0.6 & 2.15 & 0.06 & 0.00028 & 2.25 & 8.54 & globe & big & acrotony \\
\hline 46 & 2.5 & 0.6 & 1.9 & 0.06 & 0.00028 & 2.5 & 9.32 & globe & big & acrotony \\
\hline 56 & 2.5 & 0.3 & 2.2 & 0.03 & 0.00007 & 1.65 & 4.7 & globe & big & acrotony \\
\hline 57 & 2.35 & 0.15 & 2.2 & 0.03 & 0.00007 & 0.9 & 1.39 & globe & big & acrotony \\
\hline 66 & 2.85 & 0.4 & 2.45 & 0.06 & 0.00028 & 2.1 & 8.48 & globe & big & acrotony \\
\hline 68 & 2.9 & 0.45 & 2.45 & 0.06 & 0.00028 & 2.2 & 9.3 & globe & big & acrotony \\
\hline 129 & 1.7 & 0.1 & 1.6 & 0.02 & 0.0003 & 0.65 & 0.53 & globe & big & acrotony \\
\hline Average & 2.406 & 0.345 & 2.151 & 0.054 & 0.00222 & 1.8 & 5.582 & & & \\
\hline
\end{tabular}


All of the measured almond hybrids are vigorous. Consequently, it is necessary to continue our studies for breeding an almond variety that could be used as a rootstock.

\section{References}

1. Albala K (2009). Almonds along the Silk Road: The Exchange and Adaptation of Ideas from West to East. Petits Propos Culinaires, 88: 19-34.

2. Cociu V (2011). Nucul, Alunul, Migdalul. București, Editura MAST.

3. Greene C (2001). U.S. Organic Farming Emerges in the 1990s: Adoption of Certified Systems. Economic research service/USDA.

4. Hoy CF, Klonsky K, Beaujard A, Rodriguez AM (2004). Marketing Order Impact on the Organic Sector: Almonds, Kiwifruit and Winter Pears. Giannini Foundation Research Report.

5. Leeuwen GCM van, Kesteren HA van (1998). Delineation of the three brown rot fungi of fruit crops (Monilinia spp.) on the basis of quantitative characteristics. Canadian Journal of Botany 76.

6. López-López M, Rocio CM, Gonzalez-dugo V, Zarco-Tejada PJ, Fereres E (2016). Early Detection and Quantification of Almond Red Leaf Blotch Using High-Resolution Hyperspectral and Thermal Imagery.

7. Meier U (2001). Growth stages of mono-and dicotyledonous plants, BBCH Monograph.

8. Minoiu N, Lefter G (1987). Bolile şi dăunătorii speciilor de sâmburoase. Bucureşti: Editura Ceres.

9. Socias R, Gradziel TM (2017). Almonds: botany, production and uses. Boston: Cabi.

10. Șcheau V, Cociu V, Murg S, Ile C, Ivănescu R, Buie F (2007). Trei decenii de ameliorare a migdalului la S.C.D.P. ORADEA. Pitesti: 40 de ani de cercetare în pomicultură (1967-2007) la ICDP.

11. Șcheau V (1998). Migdalul. Oradea: Imprimeria de vest.

12. Syrop M (1975). Leaf curl disease of Almond caused byTaphrina deformans (Berk.) Tul. Springer-Verlag.

13. ***Food and agriculture organization. Global statistics for the almond crop. Accessed June 2019 www.fao.org

14. ${ }^{* * *}$ Ghid tehnic și economic, pomi, arbuști fructiferi și capsun (2014). Pitesti.

15. ${ }^{* * *}$ National institute of statistics. Total surface occupied by the orchards that fructify. http://statistici.insse. ro:8077/tempo-online/

16. ***Pomologia RSR VI (1967). Bucuresti: Editura Academiei Republicii Socialiste Romania. 